\title{
THE ANALYSIS OF TRANSITIVITY PROCESS OF STUDENTS' DESCRIPTIVE TEXTS
}

\author{
Tia Listiana Apendi ${ }^{1}$, Euis Rina Mulyani ${ }^{2}$ \\ ${ }^{1}$ IKIP Siliwangi \\ ${ }^{2}$ IKIP Siliwangi \\ ${ }^{1}$ Listianaapendi27@gmail.com, ${ }^{2}$ euisrinamulyani@gmail.com
}

\begin{abstract}
This research analysis transitivity process of the descriptive text written by the students at seventh grade in junior high school. The objectives of this research is to find out the use of transitivity process of students' descriptive texts and to find out the most dominant of transitivity process. This reseach analyzed 60 sentences taken from eight descriptive texts written by the students. The researcher used descriptive quantitative method to analyzed the transitivity process. The result of this research showed that there were six processes that occured in the data, there were; material process $(41,6 \%)$, mental process $(1,7 \%)$, relational process $(38,3 \%)$, behavioral process $(1,7 \%)$, verbal process $(1,7 \%)$, and existenntial process $(15 \%)$. The most dominant process found were material process and relational process. It implies that the students were aware how descriptive text should be written, because one of language features in descriptive text is using material process and relational process accordance the definition that descriptive text is describe about person, place, things, or the outward of something like daily activity during the students used simple present tense in each verbs.
\end{abstract}

Keywords: SFL, Transitivity, Descriptive text

\section{INTRODUCTION}

In English language there are four skills must be mastered by the students, one of them is writing skill. According to Scott (1996) cited in Apsari (2017) writing is direct activities used to communication. It means writing is important part of our life. Writing is a great tool because it can solidify ideas and thoughts by writing something down on paper. Linse (2006) cited in Suprijadi \& Masitoh (2015) stated that writing is a combination of process and product to discover ideas, putting them on paper and organize them to be a sentences and paragraphs. According to White and Arndt (1993) writing is the process of thinking and intelectual effort involves organizing ideas, planning, and goal setting. To make a good and readable writing, the students should be able to adjust the content with its title, organize a text, use a correct vocabulary, grammar, punctuation, and make it cohesive and coherent.

Writing can help the students to express the ideas and feelings in written form and poured it into the text. Based on 2013 revision 2017 curriculum, descriptive text is the one of writing text that should be learnt by the students of seventh grade in junior high school. Descriptive text is a text used to describing particular thing, person, and animal or event to the readers Noprianto (2017) In a broad sense, Kane (2005) cited in Suprijadi \& Masitoh (2015) defined that description is about sensory experience how something looks, sounds, tastes deals with other kind of perception used to create a visual image and to describe outward appearance of people such as activities or habbits. Wignell (1994) cited in Anggraeni, Rohmat, \& Nurhaeni (2018) 
states that descriptive text is a text that describes a particular person, place, and things. In the same book, Wignell added that descriptive text contains some elements such as generic structure, social function, and grammatical features. Descriptive text is one of English lesson that should be mastered by Indonesian students in school. Gerot \& Wignell (1995) cited in Anggraeni et al. (2018) mentions some language features of descriptive text, and one of them use clause with attributive and identifying processes.

Attributive and identifying process are two terms in Systematic Functional Linguistic. Almurashi (2018) states that Systematic Functional Linguistic (SFL) is a language approach which also known as functional grammar which is developed by M.A.K Halliday in 1960s. According to Gerot and Wignell (1995) functional grammar in SFL is different from traditional grammar and formal grammar. In SFL, there is metafunction that is the system to make a meaning of a related kind. Halliday (1994) states three functions, there are ideational metafunction, interpersonal metafunction, and textual metafunction.

In ideational metafunction, there is transitivity system as part of sub-network which refers to the predicate of a language and the participant roles with which they combined. According to Halliday (2004) transitivity is a grammatical system that expresses the world of experience into a number of types of processes that can be arranged, the experience expressed a reflection of real reality as outlined in the text or writing.

Halliday (2004) states that transitivity is the meaning of clauses or sentences, which represents the pattern of experience. Halliday (2004) discriminates six different types of transitivity process, that are material process, mental process, relational process, behavioral process, existential process, and verbal process. The first process is material process, it means the represents of process of doing and happening Halliday (2004) There are two main aspects in material process, there are actor and goal. Actor is someone or something who doing something, and goal is something is acted by the actor. Besides two main aspects, there are four participants; they are scope, recipient, client, and attribute. There are some verbs used in material process: give, send, buy, take, walk, write based on Halliday (2004)

The second is mental. According to Halliday (2004) Mental process is a process of feeling, thinking, and perceiving. Halliday also stated that Mental processes can be classified into three classes: Cognition (processes of thinking, knowing, understanding), Affection (Processes of liking, fearing), and Perception (Verbs of seeing and hearing). Mental process must always have two participants, they are a Senser (Human or conscious participant), and a Phenomenon (something which sensed). These involves verbs used in mental process: seeing, hearing, wishing, understanding, feeling, and noticing based on Halliday (2004)

The third is verbal process, that is the process of saying and meaning (Halliday, 1994). There are four participants of verbal processes; there are, sayer (someone who says), receiver (the one whom saying is directed), verbiage (a name for verbalization itself), and target (entity targetted by the process of saying). Based on Halliday (2004) there are some verbs used in verbal process: talk, say, ask, reply, suggest. 
The forth is relational process. It is a process of being and having, there are being used to identify something. Gerot and Wignell (1995) cited in Anggraeni et al. (2018) state that relational process as a process which is of being and having are involved. Relational process is divided into two parts; there are, identifying process (establish an identity) and attributive process (assign a quality). In identifying process there are token and value, and in attributive process they are carrier and attribute. These involves verbs such as is, has, will be, be, belong.

The fifth is behavioral process is the process of manifestations of inner working acting, physiological or psychological behavior (Halliday and Matthiessen, 2004) like dreaming, breathing, snoring, smiling, hiccuping, looking, watching, listening and pondering. The group of the behavioral process are material and mental processes and have only one participant which is called as Behaver

The last processes is existential process, It represent the existence of something. Usually this process use "there" as its subject. There is the only obligatory participant in this process, that is called as Existent.

Table 1. Example of Transitivity processes adapted by Halliday (2004)

\begin{tabular}{ccc} 
No. & Processes & Examples \\
\hline 1. & Material & The gardener dug a hole. \\
\hline 2. & Mental & She has forgotten to leave the key. \\
\hline 3. & Relational & Mangos taste delicious. \\
\hline 4. & Verbal & I pursuaded my mother to see a doctor. \\
\hline 5. & Behavioral & She can watch the television. \\
\hline 6. & Existential & There were a lot of people cheering for my \\
& & team.
\end{tabular}

The previous research has been analyzed about transitivity process, One of them is belong to Anggraeni et al. (2018). In that research, the researcher used transitivity to investigate descriptive text of the tenth grade in senior high school. Another research conducted by Anggun (2016) who analyzed transitivity of descriptive text from English text book meets the schematic structures and linguistic features. Other research conducted by Zahoor \& Janjua (2016) that focused on transitivity patterns in song "I am Malala".

In this research, the researcher also interest to use transitivity to analyze seventh grade students' descriptive text at seventh grade of junior high school that has a purpose to investigate their use of transitivity process of students' descriptive text and to know the most dominant process of transitivity. After knowing the most dominant process, the researcher be able to know how the use of transitivity process in students' descriptive text. The title of this research is The Analysis of Transitivity Process of Seventh Grade Students' Descriptive Text. 


\section{METHOD}

This research used descriptive quantitative method used to find out the amount and percentage of transitivity process produced by students' in writing descriptive texts in a junior high school in Cimahi, Jawa Barat, Indonesia. The reason of why the researcher chose the seventh graders because the curriculum contains descriptive text. Before the students write a descriptive text, the researcher taught them about descriptive text that consists of definition, generic structure, language features, and examples of the descriptive texts. The students wrote the descriptive texts around 45 minutes. The students were asked to write descriptive text based on the topic given by the researcher (person and place). This research analyzed eight descriptive texts written by seventh grade students of junior high school. To analyze the text, the researcher divided each paragraphs of the text into sentences to make the analyzing process more detail. Then, the researcher identified and classified the sentences based on six types of transitivity process accordance to Halliday (2004). The process of quantification was done, and finally the mosy dominant process was found and described.

\section{RESULTS AND DISCUSSION}

\section{Results}

The researcher presented the data taken from the students' descriptive text. In this research, the researcher analyzed eight the students' descriptive text based on processes of transitivity. There are material process, mental process, relational process, verbal process, behavioral process, and existential process. In this case, there are 60 sentences was found and analyzed. The distribution of each students' descriptive text can be seen in the table below.

Table. 2 Distribution of processes in each students' descriptive text

\begin{tabular}{ccccccc}
\multirow{2}{*}{$\begin{array}{c}\text { Participant } \\
\text { s }\end{array}$} & \multicolumn{7}{c}{ Processes } \\
\cline { 2 - 7 } & Material & Mental & Relational & Behavioral & Verbal & $\begin{array}{c}\text { Existe } \\
\text { ntial }\end{array}$ \\
\hline Student 1 & 2 & - & 6 & - & - & 1 \\
\hline Student 2 & - & - & 1 & - & 1 & 6 \\
\hline Student 3 & 2 & - & 3 & - & - & - \\
\hline Student 4 & 7 & - & 3 & - & - & - \\
\hline Student 5 & 1 & - & 3 & - & - & 1 \\
\hline Student 6 & 5 & 1 & 1 & - & - & - \\
\hline Student 7 & 7 & - & 4 & - & -
\end{tabular}




\begin{tabular}{ccccccc} 
Student 8 & 1 & - & 2 & 1 & - & 1 \\
\hline Total & 25 & 1 & 23 & 1 & 1 & 9
\end{tabular}

From the distribution in the table above, we can see that material process occured 25 times, mental process 1 time, relational process 23 times, behavioral 1 time, verbal 1 time, and existential 9 times.

Table. 3 Appearances of processes

Processes $\quad$ Frequency of Appearances Percentages

\begin{tabular}{ccc}
\hline Material & 25 & $41,6 \%$ \\
\hline Mental & 1 & $1,7 \%$ \\
\hline Relational & 23 & $38,3 \%$ \\
\hline Behavioral & 1 & $1,7 \%$ \\
\hline Verbal & 1 & $1,7 \%$ \\
\hline Existential & 9 & $15 \%$ \\
\hline Total & 60 & $100 \%$
\end{tabular}

The table above showed that material process is the most dominant process found in the students' descriptive text. It is about $41,6 \%$ or 25 sentences. Material process is the process of doing and happening. The second is relational process, it appears 23 times $(38,3 \%)$ which means the process of being and having. The third is existential process (the existence of something) its around 9 times $(15 \%)$. The forth is verbal process that is the process of saying and meaning, its around 1 time $(1,7 \%)$. The last are mental process that is process of thinking and feeling, and behavioral process that is the inner working of physicological. Each of them get 1 time $(1,7 \%)$.

\section{Discussion}

This part discussed the general interpretation of the processes found in the data. Based on the data calculation, there are six processes found, there are material process, mental process, relational process, behavioral process, verbal process and existential process. The explanation about each processes will be showed below:

The first is material process. the researcher found 25 material processes from all of the data analyzed. Material process is classified into two parts, there are actor and goal. The researcher found that in each sentence almost use actor and goal in the students' descriptive text. It is found by student 1 ( 2 times), student 3 ( 2 times), students 4 ( 7 times), student 5 ( 1 time), student 6 (5 
times), student 7 (7 times), and student 8 (1 time). These are some sentences from students' descriptive text used material process:

No.

Sentences

\begin{tabular}{ccc} 
& Actor & Goal \\
\hline 1. & Doraemon & Helps Nobita's family. \\
\hline 2. & Nobita & Goes to school. \\
\hline 3. & Doraemon & Lives with Nobita's family. \\
\hline 4. & I & Watch doraemon's movie. \\
\hline 5. & The teacher & Helps me to solve the problem.
\end{tabular}

The students used material process to explain what the actors did. For example, the students can distinguish the role of actor and goal in the sentence 'Doraemon helps Nobita's family', the students tried to give the goal of the actor 'Doraemon' in that sentence.

The second process is relational process. The researcher found 23 sentences from the data. In relational process divided into two parts, there are identify and attributive. In this case, relational process occured ten times, student 1 ( 6 times), student 2 (1 time), student 3 (3 times), student 4 (3 times), student 5 (3 times), student 6 ( 1 time), student 7 (4 times), and student 8 (2 times). These are the students' sentence of relational process:

No.

Sentences

\begin{tabular}{llll}
\cline { 2 - 4 } & Carrier & Attributive & Attribute \\
\hline 1. & Doraemon & Is & A cute doll. \\
\hline 2. & Nobita & Is & $\begin{array}{l}\text { Very kind and } \\
\text { friendly. }\end{array}$ \\
\hline 3. & Doraemon & Is always & $\begin{array}{l}\text { Faithful to his } \\
\text { friends. }\end{array}$ \\
\hline 4. & Mrs. Tia & Is very & Kind and friendly. \\
\hline 5. & I & Am & Proud to her.
\end{tabular}

The students used sentences with relational process to explain and identify what students described. For example, the sentence 'Doraemon is a cute doll', the students tried to give explanation what 'doraemon' is. 
The third is existential process. That processess occured nine times from the students' descriptive text. Halliday \& Matthiessen (2004) aruged that existential process defined as a process of existing something.

No.

Sentences

Existential process

\begin{tabular}{ccc}
\cline { 2 - 3 } & Existential & Existent \\
\hline 1. & There are & Historich things. \\
\hline 2. & There are & Many tourists. \\
\hline 3. & Monas is located & In jakarta. \\
\hline 4. & There are & Math, english, arts, sports, and others.
\end{tabular}

From the example above, students used existential process by using 'there are and there is' to explain the existent of something. While students used behavioral process to indicated the behavioral of something.

The forth is verbal process that is the process of saying and meaning, its relate to the information given. This processes occured two times or 3,3\% from student two and student eight. In the table below the example of students used of this process.

\begin{tabular}{cc} 
No. & Sentences \\
\hline 1. & My mother said monas very high
\end{tabular}

The sentences above prove that in verbal process the student used 'said' that acted by 'my mother' which has meaning as giving information.

The last processes are mental process and behavioral process. There are only provide one time from student six for mental process, and student two for behavioral process. Mental process is the process of thinking and feeling. While behavioral process is the inner of working relate to physicological. These are the example of those processes.

No. $\quad$ Processes

Mental Behavioral

1. Doraemon scary to the mouse. We must respect the teacher. 


\section{CONCLUSION}

Based on the result and discussion, the researcher found that there were six types of processes appeared in the data. They are material, relational, existential, mental, behavioral and verbal processes (see Halliday, 2004). The two dominance processes are; (1) material process, the process of doing and happening that occured 25 times and (2) relational process, the process of being and having that occured 23 times (out of 60 processes). It hints that the students' conceive descriptive text as a text that describes action, activity, or happened physically, bodily, and materially and it is in line with Kane (2000 cited in Suprijadi 2015) descriptive text is a text describe about people, place, or things and the form or properties of the objects like daily activity. The use of two dominance processes implied that the students aware how descriptive text should be written accordance language features of descriptive text.

\section{ACKNOWLEDGMENTS}

This article was made with true information and research results by the researcher. hard work, support from several people, and guidance from several articles related to this article help the researcher in writing this article. The researcher apologize if in this article there are some incomplete information, and thank you for all the support and cooperation during the writing of this article.

\section{REFERENCES}

Almurashi, W. (2018). An Introduction to Halliday' s Systemic Functional Linguistics. Journal for the Study of English Linguistics, Vol. 4, No(May 2016), 70-80. https://doi.org/10.5296/jsel.v4i1.9423

Anggraeni, A., Rohmat, N., \& Nurhaeni. (2018). Transitivity Analysis Of Tenth Grade Students ' Descriptive Text. Project Journal, 01(03), 295-302.

Anggun, S. K. (2016). An Analysis Of Descriptive Text In English Textbook Using Transitivity System ( A Case Study Of Reading Passages ). Journal of English and Education, 4(1), $147-158$.

Apsari, Y. (2017). The use of picture series in teaching writing recount text. Eltin Jou, 5, 5156.

Gerot, L., \& Wignell, P. (1995). Making Sense of Functional Grammar. Australia: Gerd Stabler Halliday, M.A.K. \& Matthiessen, C. M.I.M. (2004). An Introduction to Functional Grammar. London: Arnold. https://doi.org/10.4324/9780203783771

Noprianto, E. (2017). Student' s Descriptive Text Writing in SFL Perspectives. IJELTAL (Indonesian Journal of English Language Teaching and Applied Linguistics), Vol. 2(1)(December), 65-81. https://doi.org/10.21093/ijeltal.v2i1.53

Suprijadi, Dasep. \& Masitoh, S. (2015). Improving Students' Ability In Writing Descriptive Text Using Genre Based Approach (Gba) At The Eighth Grade Students Of Smp Islam Terpadu Fitrah Insani. Eltin Journal, 3(April), 38-52.

White, R., \& Arndt. V. (1993). Process Writing-A Handbook for Teachers.

Zahoor, M., \& Janjua, F. (2016). Character Construction In Tributive Songs: Transitivity Analysis Of The Song “ I Am Malala .” Trames, 20(1985), 201-213. https://doi.org/10.3176/tr.2016.2.05 